\title{
Dominika Mróz-Krysta*
}

\section{ZWROT NAKŁADÓW Z MAJĄTKU WSPÓLNEGO MAŁŻONKÓW \\ NA NIERUCHOMOŚĆ STANOWIĄCĄ MAJĄTEK OSOBISTY \\ DRUGIEGO MALŻONKA A IUS RETENTIONIS - PYTANIE \\ O CELOWOŚĆ POSZERZANIA KATALOGU WYJĄTKÓW \\ WYMIENIONYCH W ART. 461 § 2 K.C.}

\begin{abstract}
Streszczenie
Zgodnie z art. $461 \S 1$ k.c. w zw. z art. $461 \S 2$ k.c. zobowiązany do wydania cudzej rzeczy może ją zatrzymać aż do chwili zaspokojenia lub zabezpieczenia przysługujących mu roszczeń o zwrot nakładów na rzecz oraz roszczeń o naprawienie szkody przez rzecz wyrządzonej (prawo zatrzymania). Przepisu powyższego nie stosuje się, gdy obowiązek wydania rzeczy wynika z czynu niedozwolonego albo gdy chodzi o zwrot rzeczy wynajętych, wydzierżawionych lub użyczonych.

Nasuwa się pytanie o możliwość stosowania analogii do wyjątków od prawa zatrzymania wymienionych w art. 461 § 2 k.c. w sytuacji, w której po ustaniu małżeństwa (przykładowo: po rozwodzie) były małżonek zamieszkuje nieruchomość stanowiącą majątek osobisty drugiego małżonka, wbrew jego woli, powołując się na obowiązek rozliczenia nakładów z majątku wspólnego na majątek osobisty byłego małżonka.

Do opracowania przedstawionego wyżej zagadnienia zastosowałam metodę dogmatyczną, analizując aktualnie obowiązujący stan prawny, wyprowadzając wniosek

* dr Dominika Mróz-Krysta, Katedra Prawa Cywilnego, Wydział Prawa i Administracji, Uniwersytet Jagielloński, adres email: dominika.mroz-krysta@uj.edu.pl. ORCID: 0000-0002-60188776
\end{abstract}


o dopuszczalności poszerzenia wyjątków od prawa zatrzymania. Przesłankami do zastosowania analogii w prawie cywilnym są podobieństwo ze względu na istotne cechy oraz luka w prawie. W wypadku zamieszkiwania $\mathrm{z}$ rozwiedzionym małżonkiem jego nieruchomości wbrew jego woli spełnione zostały one wszystkie.

Zamieszkiwanie byłego małżonka nieruchomości drugiego wbrew jego woli jest na tyle naganne, że wykazuje podobieństwo z czynem niedozwolonym, a ustanie prawnorodzinnego tytułu do mieszkania, o którym mowa w art. 281 k.r.o. - podobieństwo do ustania stosunków prawnych o charakterze ciągłym, takich jak użyczenie.

Jak wykazano, de lege lata dopuszczalne jest stosowanie analogii z art. $461 \S 2$ k.c. tak, by były małżonek zamieszkujący nieruchomość drugiego małżonka po ustaniu małżeństwa nie mógł powołać się na prawo zatrzymania. De lege ferenda należałoby postulować ustawowe poszerzenie katalogu wyjątków od prawa zatrzymania.

Słowa kluczowe: prawo zatrzymania, analogia, nakłady, majątek osobisty, majątek wspólny

\section{Wprowadzenie}

Zgodnie z art. 461 § 1 k.c. w zw. z art. 461 § 2 k.c. zobowiązany do wydania cudzej rzeczy może ją zatrzymać aż do chwili zaspokojenia lub zabezpieczenia przysługujących mu roszczeń o zwrot nakładów na rzecz oraz roszczeń o naprawienie szkody przez rzecz wyrządzonej (prawo zatrzymania). Przepisu powyższego nie stosuje się, gdy obowiązek wydania rzeczy wynika z czynu niedozwolonego albo gdy chodzi o zwrot rzeczy wynajętych, wydzierżawionych lub użyczonych ${ }^{1}$.

Zdarza się w praktyce, że rozwiedziony małżonek odmawia zwrotu rzeczy należącej do majątku osobistego byłego małżonka, korzystając w procesie z zarzutu zatrzymania przewidzianego w art. $461 \S 1$ k.c. (ius retentionis) i domagając się rozliczenia należnych nakładów z majątku wspólnego na majątek osobisty drugiego małżonka. W wypadku gdy składnikiem majątku osobistego, na który czynione były nakłady z majątku wspólnego, jest nieruchomość, która zaspokajała potrzeby mieszkaniowe rodziny (przykładowo: grunt zabudowany domem jednorodzinnym, odrębny lokal mieszkalny), skorzystanie $\mathrm{z}$ prawa zatrzymania sprowadza się do odmowy opuszczenia nieruchomości przez roz-

1 Ustawodawca polski, w przeciwieństwie do np. francuskiego, wyliczył enumeratywnie wyjątki od prawa zatrzymania, a nie przypadki, w których prawo to przysługuje (zob. art. 2286 Code Civil). 
wiedzionego małżonka i dalszego zamieszkiwania z byłym małżonkiem, najczęściej wbrew jego woli.

Ponadto w związku z tym, że zwrotu nakładów z majątku wspólnego na majątek osobisty jednego z małżonków dochodzi się w postępowaniu o podział majątku wspólnego po ustaniu wspólności ustawowej² (niejednokrotnie postępowanie o podział majątku dotyczy tylko tej jednej kwestii), sądy uzależniają eksmisję pozwanego rozwiedzionego małżonka z nieruchomości od wykonania przez drugiego $\mathrm{z}$ byłych małżonków postanowienia w przedmiocie podziału majątku, które stwierdza obowiązek rozliczeń nakładów z majątku wspólnego na majątek osobisty drugiego małżonka. Innymi słowy - dochodzi do uwzględnienia zarzutu zatrzymania zgłoszonego przez byłego małżonka, który jest pozwanym w procesie o eksmisję. Zwrot rzeczy, czyli faktyczna realizacja eksmisji rozwiedzionego małżonka (zwrot nieruchomości), uzależniony jest zatem od rozliczenia nakładów z majątku wspólnego na majątek osobisty drugiego z małżonków ${ }^{3}$.

Tak ukształtowana praktyka - choć zgodna z literalnym brzmieniem art. 461 $\S 1$ i $§ 2$ k.c. - budzi wątpliwości, gdyż de facto prowadzi do zniweczenia funkcji postępowania o podział majątku, które - jako wtórne do ustania małżeństwa - ma na celu doprowadzenie do definitywnego zakończenia spraw związanych z małżeństwem i „rozstania się małżonków w sensie finansowym”. Uzależnienie eksmisji byłego małżonka od rozliczenia nakładów stwierdzonych w postępowaniu o podział majątku prowadzi do sztucznego ,przedłużania” relacji majątkowych i osobistych między byłymi małżonkami i tworzy zarzewie konfliktu. Jest więc sprzeczne $\mathrm{z}$ celem $\mathrm{i}$ istotą postępowania o podział majątku, jak również prowadzi do nieuzasadnionego przyznania ochrony przed eksmisją rozwiedzionemu małżonkowi w sytuacji, gdy przedmiotem majątku osobistego, na który czynione były nakłady z majątku wspólnego, jest nieruchomość przeznaczona na cele mieszkaniowe.

W kontekście powyższego rodzi się pytanie o prawną możliwość i celowość rozszerzającej wykładni katalogu wyjątków od prawa zatrzymania, przewidzianych w art. $461 \S 2$ k.c. Innymi słowy, czy możliwe i zasadne jest poszerzenie katalogu wyjątków od prawa zatrzymania o rozwiedzionego małżonka, który

2 Zob. art. 567 § 1 k.p.c.

3 Przyjmuje się w orzecznictwie, iż: „Zarzut zatrzymania nie skutkuje oddaleniem powództwa, lecz ma charakter zabezpieczający, co oznacza przy uwzględnieniu zarzutu zatrzymania, że zwrot nieruchomości powinien zostać orzeczony za jednoczesnym zwrotem przez właściciela nieruchomości nakładów lub ich wartości” (wyrok SA w Krakowie Wydział I Cywilny z 17 listopada 2016 r., I ACa 789/16, Legalis nr 1564467). 
odmawia zwrotu rzeczy należącej do majątku osobistego drugiego małżonka, zwłaszcza, jeśli jest to nieruchomość, która służyła zaspokojeniu potrzeb mieszkaniowych rodziny. W tym kontekście należałoby także rozważyć, czy ewentualne powołanie się w konkretnych okolicznościach na sprzeczność zarzutu zatrzymania z zasadami współżycia społecznego stanowi adekwatny mechanizm ochrony interesów małżonka będącego właścicielem nieruchomości.

Analizowane zagadnienie koreluje $\mathrm{z}$ tematem przewodnim konferencji „Zasada jedności prawa cywilnego a spójność regulacji prawnohandlowych i prawnorodzinnych" - dotyczy bowiem pewnego rodzaju niespójności regulacji prawnorodzinnych ${ }^{4}$, a dotyczących ustania małżeństwa, podziału majątku wspólnego, prawnorodzinnego tytułu małżonka do mieszkania drugiego małżonka i rozliczenia nakładów z majątku wspólnego oraz regulacji cywilnoprawnych w zakresie prawa zatrzymania. De lege lata powstaje pytanie o możliwość usunięcia tej niespójności $\mathrm{w}$ drodze zastosowania analogii z art. $461 \S 2$ k.c., a w konsekwencji - o niemożliwość powołania się na prawo zatrzymania przez byłego małżonka, który odmawia opuszczenia nieruchomości należącej do majątku osobistego drugiego małżonka.

Ze względu na społeczną doniosłość zaspokojenia mieszkaniowych potrzeb małżeństwa i rodziny oraz szczególną naganność zajmowania nieruchomości należącej do byłego małżonka wbrew jego woli rozważania dotyczące obowiązku „Zwrotu rzeczy” w kontekście art. $461 \S 1$ k.c. zostaną poprowadzone w odniesieniu do nieruchomości.

\section{Sytuacja prawna osoby zamieszkującej nieruchomość byłego małżonka a ustawowe wyjątki od prawa zatrzymania}

Uprawnienie do mieszkania na nieruchomości należącej w czasie trwania małżeństwa do byłego małżonka nie budzi najmniejszych wątpliwości w kontekście regulacji prawnorodzinnych, tj. art. $28^{1}$ k.r.o. W literaturze bez zastrzeżeń przyjmuje się, iż: ,uprawnienie do korzystania z mieszkania [przez drugiego małżonka - wyjaśnienie moje - D.M.-K.] jest ograniczone realizacją celu, jaki stanowi zaspokojenie potrzeb rodziny"s, a prawo małżonka do mieszkania kwali-

4 Zarówno na płaszczyźnie materialnoprawnej, jak i procesowej; art. $28^{1}$ k.r.o., art. 567 $\S 1$ k.p.c.

5 K. Michałowska, Niemajątkowe wartości życia rodzinnego w polskim prawie cywilnym, Warszawa 2017, s. 436. 
fikuje się jako prawo podmiotowe ${ }^{6}$. Pojęcie „mieszkania” z kolei należy wykładać szeroko. Przez mieszkanie na podstwie art. $28^{1}$ k.r.o. rozumie się: ,pomieszczenie, w którym można zorganizować życie"7.

Ponadto oczywiste jest, że ustanie małżeństwa (przykładowo: przez rozwód) powoduje automatycznie ustanie prawnorodzinnego tytułu do mieszkania ${ }^{8}$. Wynika z tego, że jeżeli nieruchomość przeznaczona do zamieszkania rodziny stanowiła wyłączną własność drugiego małżonka, to po ustaniu małżeństwa były małżonek, który nadal ją zamieszkuje, zajmuje ją bez tytułu prawnego. Jest zatem „zobowiązanym do zwrotu rzeczy” w rozumieniu art. $461 \S 1$ k.c. Literalna wykładnia katalogu wyjątku od prawa zatrzymania (art. $461 \S 2$ k.c.) prowadzi do wniosku, że prawo to przysługuje byłemu małżonkowi zobowiązanemu do opuszczenia nieruchomości drugiego małżonka. Oznacza to, że rozwiedziony małżonek może zamieszkiwać z byłym małżonkiem nieruchomość tego ostatniego, nawet wbrew jego woli.

W świetle powyższych okoliczności powstaje pytanie o prawną możliwość pozbawienia prawa zatrzymania byłego małżonka, który korzysta z tego prawa w odniesieniu do obowiązku opuszczenia nieruchomości należącej do drugiego z nich (czyli de facto obowiązku jej zwrotu). Przyjmuje się, że prawo zatrzymania nie ma charakteru bezwzględnego i doznaje wyjątków, a ponadto nie kreuje ochrony dłużnika o charakterze bezwzględnym? .

6 Wskazuje się, że „W ten sposób ustawodawca skonstruował swoisty tytuł prawny dla takiego małżonka, rozważane uprawnienie jest bowiem bez wątpienia prawem podmiotowym", K. Pietrzykowski, w: Kodeks rodzinny i opiekuńczy. Komentarz, red. K. Pietrzykowski, Warszawa 2018, s. 286.

7 A. Bieranowski, Prawa malżonków do mieszkania, w: Matzeńskie prawo majątkowe, Warszawa 2014, s. 278; M. Jadczak-Żebrowska, Prawa i obowiazki malżonków, Warszawa 2017, s. 293.

8 W odniesieniu do prawnorodzinnego tytułu małżonka do mieszkania i jego pochodnego charakteru: M. Olczyk, Komentarz do art. 28 (1) Kodeksu Rodzinnego i Opiekuńczego, LEX - el., Teza 1.

9 Przyjmuje się, iż: „Użyty w art. 461 § 2 k.c. zwrot «nie stosuje się» nie oznacza, że przepis ma charakter iuris cogentis, lecz oznacza jedynie niemożność powołania się na prawo zatrzymania przez zainteresowaną osobę na podstawie jej jednostronnego oświadczenia woli, jeżeli strony w tym zakresie nie postanowiły inaczej. Strony mogą również w drodze umowy poszerzyć katalog przypadków, kiedy prawo zatrzymania nie przysługuje [podkreślenie moje D.M.-K.], A. Rzetecka-Gil, Komentarz do art. 461 Kodeksu Cywilnego, Lex - el., Teza 49). Tak też: A. Rąpała, w: Kodeks cywilny. Komentarz. Tom III. Zobowiazania. Część ogólna (art. 353-534), red. M. Habdas, M. Fras, Warszawa 2018, s. 808; T. Wiśniewski, w: Kodeks cywilny. Komentarz. Tom III. Zobowiązania. Część ogólna, red. J. Gudowski, Warszawa 2018, s. 1186; K. Zagrobelny, w: Kodeks cywilny. Komentarz, red. E. Gniewek, Warszawa 2016, s. 946; A. Janiak, w: Kodeks cywilny. Komentarz. Tom II. Art. 353-626, red. M. Gutowski, Warszawa 2019, s. 1029. 
W tym kontekście należy rozważyć dwie kwestie: czy były małżonek będący właścicielem nieruchomości ma silniejszy interes $\mathrm{w}$ otrzymaniu rzeczy z powrotem niż były małżonek korzystający z prawa zatrzymania oraz czy spełnione są przesłanki stosowania analogii z art. $461 \S 2$ k.c. Warto także rozważyć, czy powołanie się na sprzeczność zarzutu zatrzymania z zasadami współżycia społecznego jest adekwatnym mechanizmem ochrony interesów byłego małżonka będącego właścicielem nieruchomości.

Nie można jednakże abstrahować od istoty prawa zatrzymania, które: „charakteryzuje się tym, iż uprawnionemu przysługuje prawo utrzymania się w posiadaniu rzeczy [podkreślenie oryginalne - D.M.-K.], która już znajduje się w dyspozycji uprawnionego, usprawiedliwionej prawem" ${ }^{10}$. Racji wyjątków od prawa zatrzymania należy z kolei „,upatrywać w dostrzeżonej przez ustawodawcę przewadze uprawnień podmiotu domagającego się wydania rzeczy nad roszczeniami podmiotu zobowiązanego do jego wydania"11.

\section{Silniejszy interes właściciela w otrzymaniu rzeczy z powrotem niż interes uprawnionego $\mathrm{z}$ prawa zatrzymania}

Prawo zatrzymania nie ma jednak charakteru bezwzględnego. Przyjmuje się w literaturze, że: „Prawo zatrzymania przyznane dłużnikowi podlega jednak pewnym ograniczeniom. Dotyczy to przypadków, w których ustawodawca uznaje, iż interes wierzyciela $\mathrm{w}$ otrzymaniu rzeczy z powrotem jest silniejszy niż interes dłużnika w otrzymaniu zwrotu wydatków"12. Wskazuje się także, iż w wypadkach wymienionych w art. $461 \S 2$ k.c. ,,interes wierzyciela przemawiający za

10 W. Popiołek, w: Kodeks cywilny. Tom II. Komentarz. Art. 450-1088. Przepisy wprowadzające, red. K. Pietrzykowski, Warszawa 2018, s. 31.

11 A. Rąpała, w: Kodeks cywilny. Komentarz. Tom III. Zobowiazania. Część ogólna (art. 353-534)...; A. Janiak w: Kodeks cywilny. Komentarz. Tom II. Art. 353-626..., s. 1029. Odnośnie do charakteru prawnego prawa zatrzymania w literaturze nie ma zgody co do stosunku tego prawa do prawa powstrzymania się ze spełnieniem świadczenia, uregulowanym w art. 488 $\S 2$ k.c. - zob. F. Zoll, w: System Prawa Prywatnego. Tom 6. Prawo zobowiąań - część ogólna. Suplement, red. A. Olejniczak, Warszawa 2010, s. 71; T. Wiśniewski, Prawo zatrzymania w Kodeksie Cywilnym, cz. 1, „Przegląd Sądowy” 1999, nr 2, s. 36-37. Na gruncie kodeksu zobowiązań - R. Longchamps de Bérier, Uzasadnienie projektu kodeksu zobowiazań. Komisja Kodyfikacyjna. Podkomisja prawa o zobowiązaniach, z. 4, Warszawa 1934, s. 313; W. Czachórski, A. Brzozowski, M. Safjan, E. Skowrońska-Bocian, Zobowiazania. Zarys wykładu, Warszawa 2009, s. 325, 755.

12 T. Wiśniewski, Glosa do uchwaty SN z dnia 29 listopada 1991 r., III CZP 124/91, „Orzecznictwo Sądów Polskich” 1992, z. 9, poz. 207. 
wydaniem rzeczy jest silniejszy niż interes dłużnika w uzyskaniu zaspokojenia lub zabezpieczenia jego roszczeń związanych z rzeczą"13.

W konsekwencji bardziej uzasadniony jest interes właściciela w otrzymaniu z powrotem nieruchomości aniżeli interes dłużnika będącego byłym małżonkiem. Nie jest ani prawnie, ani społecznie uzasadnione, aby rozwiedziony małżonek zamieszkiwał nieruchomość byłego małżonka po rozwodzie, a dodatkowo - po podziale majątku. Stanowi to jedynie sztuczne „przedłużanie” relacji majątkowych i osobistych między byłymi małżonkami. Nieruchomość stanowiąca majątek osobisty powinna przede wszystkim służyć zaspokajaniu potrzeb mieszkaniowych byłego małżonka, który jest jej właścicielem. Zważyć również należy, iż wraz z ustaniem małżeństwa przez rozwód ustaje również obowiązek wzajemnej pomocy między małżonkami, określony w art. 23 k.r.o. Ponadto często zdarza się sytuacja, że przebywanie byłego małżonka na nieruchomości należącej do drugiego małżonka jedynie utrudnia realizację zobowiązania do zwrotu nakładów. Sprzedaż spornej nieruchomości to często jedyna droga dla byłego małżonka, zobowiązanego do ich zwrotu, by uzyskać środki na spłatę należności. Zamieszkiwanie przez byłego małżonka nieruchomości drugiego utrudnia sprzedaż i pozyskanie środków na spłatę wartości nakładów poczynionych na majątek wspólny.

Na podstawie powyższych rozważań można przyjąć, że właściciel nieruchomości należącej w czasie trwania małżeństwa do majątku osobistego małżonka ma dalej idący i bardziej uzasadniony interes w eksmitowaniu byłego małżonka niż były małżonek w jej zatrzymaniu i rozliczeniu nakładów.

\section{Podniesienie zarzutu zatrzymania a nadużycie prawa podmiotowego}

Należy rozważyć, czy możliwość powołania się na sprzeczność zarzutu zatrzymania z zasadami współżycia społecznego (art. 5 k.c.) stanowi wystarczający mechanizm ochrony interesów byłego małżonka będącego właścicielem nieruchomości. Konstrukcja klauzuli generalnej daje sądom znaczną swobodę interpretacyjną i pozwala uwzględnić układ najrozmaitszych interesów wszystkich

13 W. Kocot, Prawo zatrzymania w prawie cywilnym i handlowym, „Państwo i Prawo” 1994, nr 5, s. 57. 
podmiotów w danych okolicznościach ${ }^{14}$. Nie ma jednak możliwości ustalenia jednolitych kryteriów jej zastosowania ${ }^{15}$, dlatego powoływanie się na nadużycie prawa podmiotowego nigdy nie da gwarancji pełnej ochrony interesów strony, która tej ochrony się domaga.

Jednak ze względu na cel postępowań o rozwód i o podział majątku, jakim jest definitywne rozłączenie byłych małżonków, oraz wagę prawa własności byłego małżonka ochrona interesów tego ostatniego powinna zostać zgeneralizowana i w tym sensie uniezależniona od okoliczności konkretnego przypadku.

\section{Przesłanki zastosowania analogii do wyjątków od prawa zatrzymania}

Wobec niewystarczającego mechanizmu ochrony interesów byłego małżonka będącego właścicielem nieruchomości należy także rozważyć dopuszczalność stosowania analogii z art. $461 \S 2$ k.c. do takich stanów prawnych i faktycznych, które nie zostały wymienione w tym przepisie, a wykazują istotne podobieństwo $\mathrm{z}$ użyczeniem, najmem lub dzierżawą, jak również z czynem niedozwolonym, a interes właściciela rzeczy jest bardziej uzasadniony w otrzymaniu rzeczy z powrotem niż interes osoby zobowiązanej do jej zwrotu, w zabezpieczeniu lub zaspokojeniu przysługujących jej roszczeń.

Przedmiotowego zagadnienia nie sposób rozpatrywać w oderwaniu od rozważań dotyczących analogii w prawie cywilnym. Przyjmuje się w piśmien-

$14 \mathrm{~W}$ orzecznictwie przyjęto, iż ,zasady współżycia społecznego w rozumieniu art. $5 \mathrm{KC}$ są pojęciem pozostającym w nierozłącznym związku z całokształtem okoliczności danej sprawy i w takim całościowym ujęciu wyznaczają podstawy, granice i kierunki jej rozstrzygnięcia w wyjątkowych sytuacjach, które przepis ten ma na względzie. Dlatego dla zastosowania art. $5 \mathrm{KC}$ konieczna jest ocena całokształtu szczególnych okoliczności danego wypadku w ścisłym powiązaniu nadużycia prawa z konkretnym stanem faktycznym. Stosowanie klauzuli generalnej jest uzasadnione zwłaszcza wówczas, gdy dochodzi do niezgodności funkcjonalnej i aksjologicznej pomiędzy obowiązującymi przepisami stworzonymi na miarę sytuacji typowych a konkretnym stanem faktycznym poddanym ocenie. Zwroty użyte $\mathrm{w}$ art. $5 \mathrm{KC} \mathrm{w}$ istocie nawiązują do zasad słuszności, dobrej wiary w sensie obiektywnym, zasad uczciwości obowiązujących w stosunkach cywilnoprawnych i lojalności wobec partnera oraz akceptowalnych i godnych ochrony reguł rzetelnego postępowania w stosunkach społecznych" - postanowienie Sądu Najwyższego - Izba Cywilna z 28 maja 2019 r., II CSK 587/18, Legalis nr 1942530.

15 Przyjmuje się, iż: „Konstrukcja nadużycia prawa podmiotowego pozostawia znaczny margines swobody w ocenie, czy dane zachowanie mieści się w granicach prawa podmiotowego, czy też stanowi nadużycie prawa podmiotowego. $Z$ tego powodu możliwość tworzenia przez Sąd Najwyższy ogólnych i uniwersalnych standardów interpretacyjnych jest w tym zakresie w poważnym stopniu ograniczona" - postanowienie Sądu Najwyższego - Izba Cywilna z 31 maja 2019 r., II CSK 618/18, Legalis nr 1950389. 
nictwie i judykaturze, iż: „warunkiem koniecznym stosowania analogii jest luka w ustawie"16. Przez lukę w prawie rozumie się najczęściej „taki stan rzeczy, gdy dla konkretnego stosunku społecznego, który nie jest ani prawnie obojętny, ani nie został uznany przez prawodawcę za niepodlegający unormowaniu prawnemu, nie ma normy prawnej czy to wyraźnej, czy to dającej się wyprowadzić w drodze wykładni przepisów" ${ }^{17}$. Zważyć przy tym należy, iż „wykładnia prawa musi się opierać na założeniu racjonalnego i prawidłowego działania ustawodawcy oraz na przyjęciu wewnętrznej spójności aktu prawnego i całego systemu prawa"18.

Oprócz luki przesłanką dopuszczalności zastosowania analogii jest podobieństwo stanów faktycznych podlegających ocenie prawnej. W piśmiennictwie zaakcentowano, że w tym kontekście chodzi o ,przepis normujący przypadki najbliższe, najbardziej podobne, najbardziej stosowne, bardzo zbliżone, «najbliższe, podobne do rozstrzyganego przypadku ze względu na istotne cechy»"19.

Wszystkie wymienione przesłanki są spełnione, o czym będzie szczegółowo mowa niżej.

\section{Luka w prawie}

Ochrona dłużnika wynikająca z możliwości skorzystania z prawa zatrzymania nie ma charakteru absolutnego. Prowadzi to do wniosku, iż katalog wyjątków określonych w art. $461 \S 2$ k.c. nie musi być zamknięty. W kontekście powyższego oraz art. $28^{1}$ k.r.o. rodzi się pytanie o dopuszczalność skorzystania z prawa zatrzymania przez rozwiedzionego małżonka, który ma zostać eksmitowany z lokalu mieszkalnego stanowiącego majątek osobisty drugiego z małżonków. Do postawienia tego pytania uprawnia specyfika sytuacji, w jakiej znajdują się byli małżonkowie wówczas, gdy jeden z nich jest właścicielem nieruchomości, a drugi zamieszkuje na tej nieruchomości mimo ustania małżeństwa przez rozwód, a co za tym idzie - czyni to mimo ustania pochodnego prawnorodzinnego tytułu do mieszkania, uregulowanego $\mathrm{w}$ art. $28^{1}$ k.r.o. W literaturze zaakcentowano ponadto, że uprawnienia tam przewidziane, usytuowane są w treści sto-

16 E. Kabza, Problem stosowania analogii w prawie cywilnym, „Forum Prawnicze” 2010, nr 1, s. 55; D. Mróz-Krysta, Obligacyjne skutki ustawowego prawa odstapienia od umowy, Warszawa 2014, s. 203.

17 E. Kabza, op.cit., s. 55; D. Mróz-Krysta, op.cit., s. 203.

18 E. Kabza, op.cit., s. 56; D. Mróz-Krysta, op.cit., s. 203.

19 E. Kabza, op.cit., s. 57; D. Mróz-Krysta, op.cit., s. 203. 
sunku małżeństwa, a jako elementy jego treści wygasają w następstwie ustania lub unieważnienia małżeństwa ${ }^{20}$.

Warto również podkreślić, że skoro wyjątkowy - jak by się zdawało ${ }^{21}$ - charakter regulacji art. $461 \S 2$ k.c. może zostać „przełamany” przez zasadę swobody umów ${ }^{22}$, to tym bardziej może zostać „przełamany” w sytuacji, gdy tak wiele racji przemawia za udzieleniem silniejszej ochrony właścicielowi nieruchomości uprawnionemu do jej odzyskania, w tym w szczególności naganne postępowanie rozwiedzionego małżonka, który bez żadnego uzasadnienia w obiektywnie ocenionej sytuacji majątkowej zamieszkuje z byłym małżonkiem.

Brak wymienienia obowiązku zwrotu rzeczy wynikającego $\mathrm{z}$ ustania pochodnego prawnorodzinnego tytułu do niej w treści art. $461 \S 2 \mathrm{k} \mathrm{c}$. oraz relacja temporalna pomiędzy art. $461 \S 1 \mathrm{i} \S 2$ oraz art. $28^{1}$ k.r.o. (ten ostatni przepis wszedł w życie później) uprawniają do przyjęcia, iż w prawie występuje luka. Dodatkowo za takim wnioskiem przemawia argument, że interes małżonka będącego właścicielem nieruchomości powinien być chroniony w sposób zgeneralizowany, a de lege lata ta ochrona nie jest zapewniona.

\section{Podobieństwo ze względu na istotne cechy}

Sytuacja prawna rozwiedzionego małżonka zamieszkującego nieruchomość byłego małżonka przypomina zarówno stan po ustaniu stosunków prawnych, o których mowa w art. $461 \S 2$ k.c., jak i czyn niedozwolony - czyli wykazuje podobieństwo $\mathrm{z}$ ustawowo uregulowanymi wyjątkami od prawa zatrzymania. Jednym z argumentów przemawiających za wyłączeniem prawa zatrzymania w przypadku, gdy chce z niego skorzystać rozwiedziony małżonek, jest podobieństwo tytułu prawnorodzinnego do mieszkania, o którym mowa w art. $28^{1}$ k.r.o. do stosunku użyczenia, zwłaszcza ze względu na podobieństwo celu obu instytucji (pomoc małżonkowi i biorącemu w użyczenie). Pochodny tytuł prawno-

20 M. Nazar, w: System Prawa Prywatnego. Tom 11. Prawo rodzinne i opiekuńcze, red. T. Smyczyński, Warszawa 2014, s. 446-447.

21 W literaturze akcentuje się wyjątkowy charakter wyłączeń prawa zatrzymania: „Z drugiej strony, przewidziane w art. $461 \S 2$ k.c. prawo zatrzymania cudzej rzeczy wyjątkowo nie powstaje [podkreślenie słowa „wyjątkowo” - D.M.-K., podkreślenie słów „nie powstaje” - oryginalne], gdy obowiązek wydania rzeczy wynika z czynu niedozwolonego albo gdy chodzi o zwrot rzeczy wynajętych, wydzierżawionych lub użyczonych", A. Doliwa, w: Kodeks cywilny. Komentarz, red. M. Załucki, Warszawa 2019, s. 1066, Nb 1.

22 A. Rzetecka-Gil, op.cit. 
rodzinny, jaki przysługuje małżonkowi niebędącemu właścicielem mieszkania (rozumianego w jakiejkolwiek formie), wykazuje liczne podobieństwa z umową użyczenia, zwłaszcza jeśli chodzi o cel obu instytucji (pomoc). Cel regulacji jest niewątpliwie ,istotną cechą” i znaczącym kryterium podobieństwa, jeśli chodzi o przesłanki zastosowania analogii. Podkreśla się w doktrynie swoiście pomocowy, bezinteresowny charakter umowy użyczenia ${ }^{23}$. Można w tym kontekście przyjąć, że w świetle art. 23 k.r.o. małżonkowie zobowiązani są do wzajemnej pomocy i regulacja art. $28^{1}$ k.r.o. chroniąca potrzeby mieszkaniowe małżonka niebędącego właścicielem nieruchomości jest swoistym przejawem i wyrazem tego obowiązku ${ }^{24}$. Warto również zwrócić uwagę, że skoro ustanie stosunku prawnego nawiązywanego z chęci dobrowolnej pomocy (użyczenie) uzasadnia słabszą ochronę dłużnika zobowiązanego do wydania rzeczy, to tym bardziej uzasadniona jest jego słabsza ochrona w sytuacji, gdy pomoc na jego rzecz była obowiązkiem właściciela rzeczy (w małżeństwie, zgodnie z art. 23 k.r.o.).

Kolejną istotną cechą, ze względu na którą zamieszkiwanie przez rozwiedzionego małżonka nieruchomości byłego małżonka uzasadnia analogię z wyłączeniami prawa zatrzymania, jest podobieństwo ustania małżeństwa i ustania stosunków prawnych o charakterze ciągłym, wymienionych w art. $461 \S 2$ k.c. Ciągły charakter porównywanych stosunków prawnych i skutki ich wygaśnięcia to niewątpliwie podobieństwo ze względu na ,cechy istotne” z punktu widzenia przesłanek stosowania analogii. Nie należy tracić z pola widzenia, iż ustawodawca przewidział wyjątki od prawa zatrzymania po ustaniu stosunków prawnych o charakterze ciągłym (użyczenie, najem dzierżawa) i w takich sytuacjach uznał za priorytetowy interes właściciela rzeczy w otrzymaniu jej z powrotem. W literaturze wykształcił się pogląd, iż: „Prawo zatrzymania nie przysługuje więc

23 Odnośnie do użyczenia przyjmuje się w doktrynie, iż: „Jak wynika z przepisu art. 710 k.c. przez umowę użyczenia użyczający (komodant) zobowiązuje zezwolić biorącemu (komodatariuszowi) na bezpłatne używanie oddanej mu w tym celu rzeczy na czas oznaczony lub nieoznaczony. Jest to w istocie bezinteresowne pozbawienie się użytku określonej rzeczy ze strony komodanta dla wygody komodatariusza. Umowa użyczenia, motywowana najezęściej chęcią przyjścia z pomocą osobom bliskim, ma na celu przysporzenie przez użyczającego korzyści biorącemu, który bezpłatnie może korzystać z rzeczy użyczającego" [podkreślenie moje - D.M.-K.], Z. Gawlik, A. Janiak, K. Kopaczyńska-Pieczniak, G. Kozieł, E. Niezbecka, T. Sokołowski, w: Komentarz do art. 710 Kodeksu Cywilnego, red. A. Kidyba, LEX - el., Teza 3.

$24 \mathrm{Na}$ gruncie uprzednio obowiązującego stanu prawnego podnoszono, że: „obowiązek wzajemnej pomocy może w konkretnych okolicznościach stanowić podstawę do udzielenia małżonkowi ochrony prawnej przez umożliwienie mu korzystania z lokalu mieszkalnego stanowiącego odrębny (obecnie osobisty) majątek jego współmałżonka”, K. Pietrzykowski, w: Kodeks rodzinny i opiekuńczy. Komentarz..., s. 286. 
stronom umów o charakterze ciągłym (np. umowy najmu dzierżawy, umowy o pracę), których rozwiązanie działa ex nunc"25. Wskazane przykłady, w tym niewymieniona w art. $461 \S 2$ k.c. umowa o pracę, sugerują, iż kreuje się swoistą regułę ogólną, mówiącą o tym, że w przypadku stosunków prawnych o charakterze ciągłym, których rozwiązanie skutkuje wyłącznie na przyszłość, interes właściciela w otrzymaniu rzeczy z powrotem - ze względu właśnie na tę ciągłość stosunku prawnego - jest bardziej uzasadniony aniżeli ochrona dłużnika wynikająca z konieczności zabezpieczenia lub zaspokojenia jego roszczeń związanych $\mathrm{z}$ rzeczą. W tym kontekście warto zwrócić uwagę na podobieństwo małżeństwa - które jest pierwotnym czynnikiem i motywem regulacji art. $28^{1}$ k.r.o., lecz nie jest umową - do stosunków prawnych o charakterze ciągłym. Dodać należy, iż w założeniu przepisów k.r.o. małżeństwo jest związkiem o charakterze trwałym, którego unieważnienie, ustalenie nieistnienia czy rozwiązanie wymaga interwencji sądu na podstawie ściśle określonych reguł i przesłanek. Co więcej, rozwiązanie małżeństwa przez rozwód mocą wyroku skutkuje ex nunc, tj. na przyszłość, konstytuując nowy stan prawny zarówno między samymi, byłymi już małżonkami, jak i wobec osób trzecich. W tym kontekście charakter prawny ustania małżeństwa, a co za tym idzie - ustania pochodnego tytułu prawnorodzinnego jednego z małżonków do mieszkania - uzasadnia jego podobieństwo do ustania stosunków prawnych o charakterze ciągłym, a tym samym: dalej idącą ochronę właściciela nieruchomości aniżeli dłużnika zobowiązanego do jej wydania.

Kolejnym wyjątkiem od prawa zatrzymania jest obowiązek wydania rzeczy wynikający z czynu niedozwolonego. Stan ciągłego zamieszkiwania przez byłego małżonka nieruchomości drugiego z rozwiedzionych małżonków przy braku jakiegokolwiek uzasadnienia prawnego i faktycznego jest na tyle naganne, że wykazuje podobieństwo z czynem niedozwolonym, a zatem z kolejnym wyłączeniem prawa zatrzymania ${ }^{26}$. Naganna ocena opisanego wyżej postępowania byłego małżonka to kolejna istotna cecha świadcząca o podobieństwie jako przesłance zastosowania analogii. Powyższe zapatrywanie jest o tyle uzasadnione,

25 W. Kocot, op.cit., s. 57.

26 Trzeba mieć na względzie, że do odmiennych wniosków może doprowadzić aprobata poglądu wyrażonego przez T. Wiśniewskiego: „Jeżeli chodzi o wyłączenie prawa zatrzymania z powodu czynu niedozwolonego, to trzeba stwierdzić, że czynem takim nie jest sama odmowa zwrotu rzeczy przez posiadacza, jeżeli tylko objęcie jej w posiadanie miało swój tytuł prawny lub nastąpiło w dobrej wierze. Również posiadania w złej wierze nie można utożsamiać z czynem niedozwolonym, chociaż nieraz te sytuacje będą się pokrywać”, T. Wiśniewski, w: Kodeks cywilny. Komentarz ..., s. 1186. 
iż w literaturze przyjęto szeroką koncepcję czynu niedozwolonego na gruncie art. $461 \S 2$ k.c. ${ }^{27}$

Stwierdzić należy, iż zamieszkiwanie u rozwiedzionego małżonka wbrew jego woli i bez oparcia w stanie prawnym, po rozwodzie i po podziale majątku, stanowi sytuację składającą się na szeroko rozumianą sprzeczność z prawem, a w związku z tym można ją zakwalifikować jako czyn niedozwolony w rozumieniu art. $461 \S 2$ k.c. Zważyć również należy, iż cytowani autorzy nie posługują się pojęciem „sprzeczności z ustawą”, a „sprzeczności z prawem”. Jest to pojęcie niewątpliwie szersze i zawiera w swoim zakresie znaczeniowym również sprzeczność z zasadami współżycia społecznego czy też ogólnie rozumianą sprzeczność z porządkiem prawnym.

Można również w tym kontekście, wobec przyjętej szerokiej koncepcji deliktu, argumentować, że zamieszkiwanie nieruchomości byłego małżonka po rozwodzie wbrew jego woli jest czynem niedozwolonym, a zatem mieści się już w ustawowym katalogu wyjątków od prawa zatrzymania. Wówczas mechanizm stosowania analogii nie byłby potrzebny. Jednak należałoby przyjąć, że w tym wypadku interes byłego małżonka będącego właścicielem nieruchomości nie byłby chroniony w sposób zgeneralizowany, ponieważ ocena czy doszło do czynu niedozwolonego byłaby zbyt uzależniona od indywidualnych okoliczności sprawy.

\section{Wnioski}

Postępowania o rozwód i o podział majątku mają doprowadzić do rozłączenia małżonków pod kątem zarówno osobistym, jak i majątkowym. Ewentualne zabezpieczenie potrzeb mieszkaniowych czy roszczeń alimentacyjnych rozwiedzionego małżonka regulują odrębne instytucje prawne przewidziane k.r.o., które mają charakter ścisły. Artykuł 461 k.c. nie może stanowić podstawy do legitymizowania mieszkania $\mathrm{z}$ rozwiedzionym małżonkiem bez zgody drugiego byłego małżonka i poza ramami, jakie przewidują przepisy k.r.o. Granice ochrony i zabezpieczenia potrzeb mieszkaniowych byłego małżonka wyznacza instytucja orzeczenia o sposobie korzystania z mieszkania do czasu podziału majątku

27 Wyrażono pogląd, iż: „Przez pojęcie czynu niedozwolonego nie można rozumieć tylko deliktów cywilnych, o których mowa w kodeksie cywilnym (art. 415 i n. k.c.), ale wszelkie sytuacje sprzeczne z prawem", M.H. Koziński, Glosa do wyroku SN z dnia 31 stycznia 2002 r., IV CKN 651/00, „Przegląd Sądowy” 2003, nr 10, s. 127; A. Rzetecka-Gil, op.cit. 
w wyroku rozwodowym ${ }^{28}$, zaś wystarczającym zabezpieczeniem interesów byłego małżonka, któremu przysługuje zwrot nakładów z majątku wspólnego na majątek osobisty drugiego małżonka, są mechanizmy umożliwiające egzekucję tej należności. Dodatkowo brak uwzględnienia zarzutu zatrzymania z uwagi na zastosowanie art. $461 \S 2$ k.c. nie pozbawia strony możliwości dochodzenia nakładów w odrębnym procesie ${ }^{29}$.

Zważyć również należy, iż wraz z ustaniem małżeństwa przez rozwód ustaje również obowiązek wzajemnej pomocy między małżonkami, określony w art. 23 k.r.o. Granice ochrony i zabezpieczenia potrzeb mieszkaniowych byłego małżonka wyznacza instytucja orzeczenia o sposobie korzystania z mieszkania do czasu podziału majątku w wyroku rozwodowym, zaś wystarczającym zabezpieczeniem interesów byłego małżonka, któremu przysługuje zwrot nakładów z majątku wspólnego na majątek osobisty drugiego małżonka, są mechanizmy umożliwiające egzekucję tej należności.

Podnosi się, iż: „W doktrynie dominuje ostatnio przekonanie, że stosunek k.r.o. i k.c. jest taki, jaki istnieje między lex specialis a lex generalis" ${ }^{30}$. Aprobata tego zapatrywania prowadzi do wniosku, że skoro interesy rozwiedzionego małżonka rozumiane jako potrzeby mieszkaniowe czy pomoc w zakresie świadczeń alimentacyjnych chronią - w ściśle określonych przypadkach - przepisy k.r.o., to brak jest podstaw do rozszerzania tej ochrony o przyznanie eksmitowanemu byłemu małżonkowi prawa zatrzymania. Nie sposób w tym zakresie pominąć specyfiki stosunków rodzinnoprawnych oraz podobieństwa pochodnego prawa małżonka do mieszkania do stosunków prawnych uzasadniających wyłączenie prawa zatrzymania.

Przedstawione powyżej racje i argumenty wywołują poważne wątpliwości co do zakresu stosowania art. $461 \S 1$ i $§ 2$ k.c. w kontekście art. $28^{1}$ k.r.o. w odniesieniu do rozwiedzionego małżonka, który zamieszkuje z byłym małżonkiem na jego nieruchomości, a wobec doniosłości prawnej oraz społecznej małżeństwa i jego rozwiązania zachodzi konieczność wykładni cytowanych wyżej przepisów. Spełnione są wszystkie przesłanki zastosowania analogii z art. 461 $\S 2$ k.c. - tj. luka w prawie oraz podobieństwo ze względu na istotne cechy.

28 Zob. K. Pietrzykowski, Kodeks rodzinny i opiekuńczy. Komentarz..., s. 286.

29 Wyrok SA w Warszawie - VI Wydział Cywilny z 24 marca 2016 r., VI ACa 67/07, Legalis $\mathrm{nr} 1460551$.

30 T. Smyczyński, w: System Prawa Prywatnego. Tom 11. Prawo Rodzinne i Opiekuńcze, red. T. Smyczyński, Warszawa 2014, s. 35. 
Zamieszkiwanie z rozwiedzionym małżonkiem jego nieruchomości wbrew jego woli spełnia wszystkie przesłanki zastosowania analogii z art. $461 \S 2$ k.c., a brak bezwzględnego charakteru tego przepisu - uprawnia do jej zastosowania.

W kontekście przedstawionych rozważań oraz mając na uwadze fakt, że prawo zatrzymania nie ma charakteru bezwzględnego, a co za tym idzie - brakuje podstaw do przyjęcia bezwzględnego charakteru wynikającej z niego ochrony dłużnika, przyjąć należy, iż prawo zatrzymania nie przysługuje rozwiedzionemu małżonkowi w sytuacji eksmitowania go z nieruchomości należącej do drugiego małżonka. De lege lata wniosek ten można wyprowadzić z zastosowania analogii $\mathrm{z}$ art. $461 \S 2$ k.c. De lege ferenda należałoby postulować ustawowe poszerzenie wyjątków od prawa zatrzymania o rozwiedzionego małżonka zobowiązanego do opuszczenia nieruchomości drugiego małżonka.

\section{Literatura}

Bieranowski A., Prawa matżonków do mieszkania, w: Matżenskie prawo majątkowe, Warszawa 2014.

Czachórski W., Brzozowski A., Safjan M., Skowrońska-Bocian E., Zobowiązania. Zarys wyktadu, Warszawa 2009.

Doliwa A., w: Kodeks cywilny. Komentarz, red. M. Załucki, Warszawa 2019.

Gawlik Z., Janiak A., Kopaczyńska-Pieczniak K., Kozieł G., Niezbecka E., Sokołowski T., w: Komentarz do art. 710 Kodeksu Cywilnego, red. A. Kidyba, LEX - el., Teza 3.

Jadczak-Żebrowska M., Prawa i obowiq̨zki malżonków, Warszawa 2017.

Janiak A., w: Kodeks cywilny. Komentarz. Tom II. Art. 353-626, red. M. Gutowski, Warszawa 2019.

Kabza E., Problem stosowania analogii w prawie cywilnym, „Forum Prawnicze” 2010, nr 1.

Kocot W., Prawo zatrzymania w prawie cywilnym i handlowym, „Państwo i Prawo” 1994, nr 5.

Koziński M.H., Glosa do wyroku SN z dnia 31 stycznia 2002 r., IV CKN 651/00, „Przegląd Sądowy" 2003, nr 10.

Longchamps de Bérier R., Uzasadnienie projektu kodeksu zobowiąań. Komisja Kodyfikacyjna. Podkomisja prawa o zobowiazaniach, z. 4, Warszawa 1934.

Michałowska K., Niemajątkowe wartości życia rodzinnego w polskim prawie cywilnym, Warszawa 2017. 
Mróz-Krysta D., Obligacyjne skutki ustawowego prawa odstapienia od umowy, Warszawa 2014.

Olczyk M., Komentarz do art. 28 (1) Kodeksu Rodzinnego i Opiekuńczego, LEX - el., Teza 1.

Nazar M., w: System Prawa Prywatnego. Tom 11. Prawo rodzinne $i$ opiekuńcze, red. T. Smyczyński, Warszawa 2014.

Pietrzykowski K., w: Kodeks rodzinny i opiekuńczy. Komentarz, red. K. Pietrzykowski, Warszawa 2018.

Popiołek W., w: Kodeks cywilny. Tom II. Komentarz. Art. 450-1088. Przepisy wprowadzające, red. K. Pietrzykowski, Warszawa 2018.

Rąpała A., w: Kodeks cywilny. Komentarz. Tom III. Zobowiazania. Czesść ogólna (art. 353-534), red. M. Habdas, M. Fras, Warszawa 2018.

Rzetecka-Gil A, Komentarz do art. 461 Kodeksu Cywilnego, Lex - el., Teza 49.

Smyczyński T., w: System Prawa Prywatnego. Tom 11. Prawo Rodzinne i Opiekuńcze, red. T. Smyczyński Warszawa 2014.

Wiśniewski T., Glosa do uchwały SN z dnia 29 listopada 1991 r., III CZP 124/91, „Orzecznictwo Sądów Polskich”1992, z. 9, poz. 207.

Wiśniewski T., w: Kodeks cywilny. Komentarz. Tom III. Zobowiązania. Część ogólna, red. J. Gudowski, Warszawa 2018;

Wiśniewski T., Prawo zatrzymania w Kodeksie Cywilnym, cz. 1, „Przegląd Sądowy” 1999, nr. 2.

Zagrobelny K., w: Kodeks cywilny. Komentarz, red. E. Gniewek, Warszawa 2016.

Zoll F., w: System Prawa Prywatnego. Tom 6., Prawo zobowiązań-część ogólna. Suplement, red. A. Olejniczak, Warszawa 2010.

\section{Orzecznictwo}

Postanowienie Sądu Najwyższego - Izba Cywilna z 28 maja 2019 r., II CSK 587/18, Legalis nr 1942530.

Postanowienie Sądu Najwyższego - Izba Cywilna z 31 maja 2019 r., II CSK 618/18, Legalis nr 1950389.

Wyrok SA w Krakowie Wydział I Cywilny z 17 listopada 2016 r., I ACa 789/16, Legalis nr 1564467.

Wyrok SA w Warszawie - VI Wydział Cywilny z 24 marca 2016 r., VI ACa 67/07, Legalis nr 1460551. 


\title{
THE REIMBURSEMENT OF THE EXPENDITURES FROM \\ THE COMMON PROPRIETY OF THE SPOUSES ON PERSONAL \\ REAL ESTATE PROPRIETY OF ONE OF THEM - IS IT POSSIBLE TO EXTEND THE EXCEPTIONS TO THE RIGHT OF RETENTION
}

\begin{abstract}
Summary
Pursuant to the article $461 \S 1$ of Polish Civil Code (hereinafter referred to as: "CC") related to the art. $461 \S 2 \mathrm{CC}$, a person obliged to release somebody else's thing may retain it until his claims for the reimbursement of expenditures on the thing of claims for the redress of the damage inflicted by the thing are satisfied or secured (right of retention). The aforementioned provision shall not apply when the duty to release the thing results from a tort or where it concerns the return of things which have been leased, rented or loaned for use.

There was a question to put, whether it is admissible to extend the scope of the exceptions to the right of retention, regulated in the art. $461 \S 2 \mathrm{CC}$, by the situation of ex-spouse who uses the real estate of another after the termination of marriage and contrary to his will.

To elaborate this question, the dogmatic method of analysis has been used which is focused on the applicable law and has led to the conclusion that the extension of the exceptions to the right of retention is possible by the way of analogy. The reason by analogy in civil law needs the similarities and the loophole in law. In the case of use the real estate of the ex-spouse after the divorce fulfills all the aforementioned premises. The use of the real estate property of the ex-spouse, contrary to the will of the first of them, is so reprehensible that is similar to the tort. Moreover, the termination of the family legal tittle to real estate property of another spouse (which terminates simultaneously with the divorce and is regulated id the art. 281 of Polish Family and Guardianship Code) is similar to the termination of the continuous obligations, as for example the loan for use.

As proved, it is admissible to create the analogy to the article $461 \S 2 \mathrm{CC}$ as the ex-spouse using the real property of another one, could not profit the right of retention.
\end{abstract}

Keywords: right of retention, analogy, expenditures, personal property, common property 